\title{
Deep Denitrification of the Simulated Coastal Secondary Effluent with High Chloride Ion by Electrolysis
}

\author{
Yaozong Zhang*, Bo Pang, Guozhu Bo, Xinyuan Zhang, Wei Zhang \\ College of Civil and Architectural Engineering, North China University of Science and Technology, \\ Tangshan 063000, PR China
}

Received: 24 April 2020

Accepted: 6 September 2020

\begin{abstract}
In this study, we proposed electrolysis method to remove $\mathrm{TN}$ of the simulated coastal secondary effluent with high chloride ion concentration. TN, nitrate- $\mathrm{N}$, ammonia-N nitrite-N were detected to evaluate the evolution of nitrogen. Under the set conditions, Nitrate-N, ammonia-N removal rate and nitrite- $\mathrm{N}$ concentration increased with the rising FRC concentration. The higher the initial nitrate- $\mathrm{N}$, the lower the ammonia-N removal rate and the higher nitrite- $\mathrm{N}$ accumulation. The nitrate-N concentration was almost not influenced by ammonia- $\mathrm{N}$, and nitrite- $\mathrm{N}$ accumulation was greatly influenced by the ammonia-N and nitrate-N. TN removal rate got up to from $87.6 \%$ to $50.0 \%$ without the influence of COD. COD could greatly influence the removal of ammonia-N but little for the removal of nitrate-N and nitrite- $\mathrm{N}$ accumulation. The TN removal rates reached from $68.0 \%$ to $57.2 \%$ with the influence of COD. All the TN index met the discharge standard no higher than $15 \mathrm{mg} / \mathrm{L}$. The conversion between nitrate-N and ammonia-N did happen and intermediate product nitrite- $\mathrm{N}$ could be produced by nitrate- $\mathrm{N}$ and ammonia-N. The application of the electrolysis method on the removal of TN in effluent improved the understanding the TN removal mechanism and proposed a promising and reliable method for practical engineering.
\end{abstract}

Keywords: electrochemistry, nitrate-N, ammonia-N, chloride ion, denitrification

\section{Introduction}

In coastal areas of China, underground water level is usually higher than that inland. Uneven settlement of drainage pipes causes serious leakage. This directly leads to high chloride ion concentration in the influent of WWTP and its concentration may reach $3000 \mathrm{mg} / \mathrm{L}$

*e-mail: zyaozong@163.com or higher. In comparison, the value of chloride ion in municipal WWTP in the inland is approximately $100 \mathrm{mg} / \mathrm{L}$. Given the fact, could the chloride ion play a role in removing total (TN) process.

Total nitrogen (TN) is taken as a key water quality index in wastewater treating process, which may cause water eutrophication [1] and oxygen deficiency. The methods of removing TN include chemical [2], biological and biochemical methods. It is a common method and feasible way to remove $\mathrm{TN}$ via biological process so as to meet the rigorous $\mathrm{TN}$ discharge limit 
value $15 \mathrm{mg} / \mathrm{L}$ according to level $\mathrm{B}$ of the standard [3] nowadays. However, biological approach has its own limitation, because it requires longer treating time [4], enough carbon sources [5] and many structures. To this end, it is urgent to propose a new method to effectively and directly remove TN in costal WWTP to meet the discharge standard.

In recent years, electrochemical technology, as an alternative method for TN removing, has been attracting much attention. The method enjoys such advantages as producing no sludge, low investment, no carbon source required and environmental friendliness [6-10]. However, much of the research focused on either oxidation of ammonia-N or the reduction of nitrate-N. There is only a little research simultaneously focusing on the two reactions, and much less in WWTP in coastal areas, because of the complexity and uncertainty during the reaction.

Electrolysis process includes ammonia-N oxidation and nitrate- $\mathrm{N}$ reduction. For ammonia-N oxidation, the electrolysis process carries out usually with the existence of chloride ion. Hypochlorous acid being produced, ammonia- $\mathrm{N}$ is oxidized to several productsnitrite, nitrogen gas and some nitrogen oxides [11]. For nitrate-N reduction, the nitrate- $\mathrm{N}$ concentration in wastewater could be reduced, such products might be found as the nitrogen gas (the main product), nitrite-N, ammonia- $\mathrm{N}$ and some other nitrogen oxides $[12,13]$. However, some researchers think that ammonia- $\mathrm{N}$ is the main product of the nitrate reduction, especially when initial nitrate- $\mathrm{N}$ concentration is high $[14,15]$. The reduced nitrate- $\mathrm{N}$ can reach a relatively low level, but hard to be removed completely [16, 17]. During the whole electrolysis process, over-oxidation and overreduction can occur with by-products produced. The nitrogen gas is the target product [18] and the removal of TN is what we concerned in practical engineering. Based on the analysis, if the chloride ion could be electrolyzed to hypochlorous acid, the acid oxidizes ammonia- $\mathrm{N}$ and by-products, and then the oxidized byproducts could be reduced to nitrogen gas or other byproducts, the process could produce more nitrogen gas and improve the $\mathrm{TN}$ removal.

Combining the above analysis and the fact of costal WWTP with high chloride ion and low carbon source, the experiment takes $\mathrm{Ti} / \mathrm{IrO}_{2}$ [19-21], $\mathrm{Cu}[22,23]$ as the anode and cathode respectively to treat the water samples, The simulated water sample was made, some water quality indexes were detected to evaluate the TN removal law.

\section{Material and Methods}

\section{Electrodes and Apparatus}

Three electrodes were selected in the experiment. $\mathrm{Cu}$ (Shenzhen Yunding Metal Material Co., Ltd) and $\mathrm{Ti} / \mathrm{IrO}_{2}$ (Baoji Longsheng Nonferrous Metals Corporation) were chosen as the cathode and anode, respectively. The required three plates were designed $5 \mathrm{~cm} \times 6.5 \mathrm{~cm} \times 0.1 \mathrm{~cm}$. The $\mathrm{Cu}$ electrode was embedded between two $\mathrm{Ti} / \mathrm{IrO}_{2}$ electrodes, and the distance between them was $10 \mathrm{~mm}$. The saturated calomel electrode (Shanghai Yueci Electronic Technology Co., Ltd.) was taken as the reference electrode (shown in Fig. 1).

An electrochemical workstation was purchased from Tianjin Lanlike chemical and electricity high technology Co., Ltd. The equipment was made of Polymethyl methacrylate with the effective volume $250 \mathrm{~mL}$ (length, width and height was $5 \mathrm{~cm}, 6 \mathrm{~cm}$ and $12 \mathrm{~cm}$ respectively). The equipment was set on the electromagnetic stirrer.

\section{Experimental Method and Conditions}

In order to take the simulated water as a typical sample and better approximate the real wastewater, nitrate-N, ammonia-N and carbon oxygen demand (COD) concentration referred to the Grade $1 \mathrm{~B}$ in Discharge Standard of Pollutants for Municipal Wastewater Treatment Plant (GB18918-2002) (Chinese national standard) and was configured into different step concentrations. Superior pure potassium hydrogen phthalate and analytically pure $\mathrm{KNO}_{3}, \mathrm{NH}_{4} \mathrm{Cl}$ are used to configure $\mathrm{COD}$, nirate- $\mathrm{N}$ and ammonia-N solution. The water for the experiment was deionized water. Analytically pure $\mathrm{NaCl}$ was used to adjust the chloride ion concentration in solution.

The concentration of $\mathrm{NO}_{3}^{-}, \mathrm{NO}_{2}^{-}, \mathrm{Cl}^{-}$was detected by ion chromatography Ammonia-N was determined by Nessler's reagent spetcrophotometry and COD was measured by potassium dichromate method and the

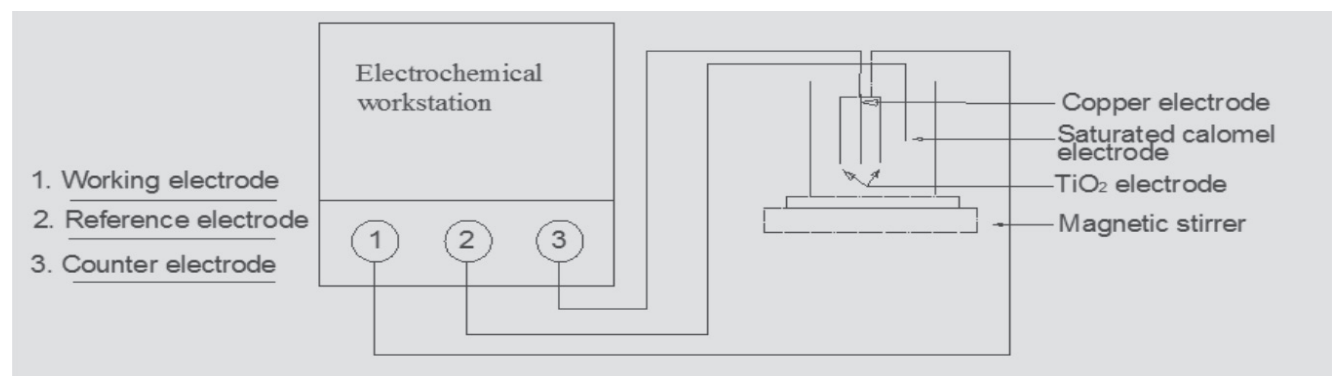

Fig. 1. Experimental equipment schematic diagram. 
effect of chloride ion on COD was eliminated by adding mercury sulfate. All the methods were mentioned in Water and Wastewater Analysis Method (4 ${ }^{\text {th }}$ edition).

In preliminary optimization experiments, the electrodes $\mathrm{Ti} / \mathrm{IrO}_{2}$ and $\mathrm{Cu}$ were chosen as anode and cathode. Cathode voltage was $-1.6 \mathrm{~V}$. The electrolytic time was set within 60 mins so that it could meet the TN index discharge standard $15 \mathrm{mg} / \mathrm{L}$ (the value mentioned in the introduced standard) and leave some space. So the next experimental parameters were fixed as before.

\section{Oxidation and Reduction Reaction Equation}

During the electrolysis, on the surface of anode, $\mathrm{Cl}^{-}$ transfers to $\mathrm{Cl}_{2}$ losing electrons and then hydrolyzes into $\mathrm{HClO}$, which can react with reductive nitrogenous substances to give oxidation nitrogenous products. Nearby cathode, nitrate gets electron, then converts to nitrite, ammonia or nitrogen gas. The possible main reactions are listed as Table 1.

\section{Results and Discussion}

\section{Parameters under Different Chloride Concentrations}

Fig. 2 shows the variation of four different parameters, namely, free residual chloride (FRC), nitrate- $\mathrm{N}$, nitrite-N and ammonia-N under different chloride ion concentrations. The initial ammonia- $\mathrm{N}$ and nitrate- $\mathrm{N}$ concentration were $10 \mathrm{mg} / \mathrm{L}$ and $20 \mathrm{mg} / \mathrm{L}$, respectively.

In 30 mins, the FRC concentration increased with the rise of initial chloride ion concentration, but no obvious value difference appeared. The reaction on the anode referred to equation $(1,2,3,4)$. When the initial chloride ion concentration was $200 \mathrm{mg} / \mathrm{L}, 60 \mathrm{mins}$ electrolysis saw the FRC reaching $1.1 \mathrm{mg} / \mathrm{L}$. When the

Table 1. Referred equation of possible oxidation and reduction reaction [24-26].

\begin{tabular}{|c|c|}
\hline $2 \mathrm{Cl}^{-} \rightarrow \mathrm{Cl}_{2}+2 \mathrm{e}^{-}$ & 1 \\
\hline $\mathrm{Cl}_{2}+\mathrm{H}_{2} \mathrm{O} \rightarrow \mathrm{HClO}+\mathrm{H}^{+}+\mathrm{Cl}^{-}$ & 2 \\
\hline $\mathrm{HClO} \rightarrow \mathrm{ClO}^{-}+\mathrm{H}^{+}$ & 3 \\
\hline $3 \mathrm{ClO}^{-}+2 \mathrm{NH}_{4}^{+} \rightarrow \mathrm{N}_{2} \uparrow+3 \mathrm{H}_{2} \mathrm{O}+2 \mathrm{H}^{+}+3 \mathrm{Cl}^{-}$ & 4 \\
\hline $3 \mathrm{ClO}^{-}+\mathrm{NH}_{4}^{+} \rightarrow \mathrm{NO}_{2}^{-}+\mathrm{H}_{2} \mathrm{O}+3 \mathrm{Cl}^{-}+\mathrm{H}^{+}$ & 5 \\
\hline $\mathrm{ClO}^{-}+\mathrm{NO}_{2}^{-} \rightarrow \mathrm{NO}_{3}^{-}+\mathrm{Cl}^{-}$ & 6 \\
\hline $\mathrm{NO}_{3}^{-}+\mathrm{H}_{2} \mathrm{O}+2 \mathrm{e}^{-} \rightarrow \mathrm{NO}_{2}^{-}+2 \mathrm{OH}^{-}$ & 7 \\
\hline $\mathrm{NO}_{3}^{-}+3 \mathrm{H}_{2} \mathrm{O}+5 \mathrm{e}^{-} \rightarrow-\mathrm{N}_{2} \uparrow+6 \mathrm{OH}^{-}$ & 8 \\
\hline $\mathrm{NO}_{3}^{-}+6 \mathrm{H}_{2} \mathrm{O}+8 \mathrm{e}^{-} \rightarrow \mathrm{NH}_{3}+9 \mathrm{OH}^{-}$ & 9 \\
\hline
\end{tabular}

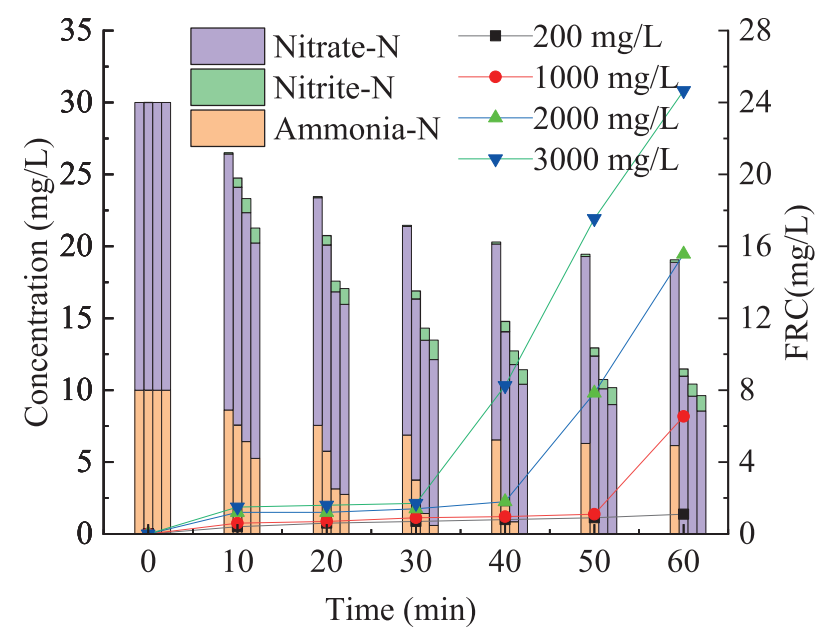

Fig. 2. Variation of the tested parameters with different chloride concentrations. (On above column chart, the different color columns $\square, \square$ and $\square$ represent nitrate-N, nitrite-N and ammonia-N, respectively; in each four-column group, the parameters were conducted under the initial chlorine concentration being 200,1000,2000,3000 mg/L from left to right; in the line+symbol diagram, The FRC variation was also obtained under four different initial chlorine concentrations.)

initial chloride concentration was $1000 \mathrm{mg} / \mathrm{L}$, the FRC initially increased starting with the time 50 mins. For the chloride concentration $2000 \mathrm{mg} / \mathrm{L}$ and $3000 \mathrm{mg} / \mathrm{L}$, the initial increasing time started from $40 \mathrm{mins}$ and 30 mins respectively. The rising rate shared a similar trend, but the time FRC concentration began rising was related to the initial chloride ion concentration. The higher of the initial chloride ion concentration was, the earlier of the time for FRC rose obviously. The key was chloride ion concentration-controlled. With the chloride ion concentration rising, its gradient close to anode changed more slightly. Moreover, the FRC could oxidize the ammonia-N more quickly. But for low chloride concentration, the reaction process changed slowly.

For the variation of ammonia-N, when the initial chloride ion concentration was $200 \mathrm{mg} / \mathrm{L}$, the ammonia-N concentration decreased slowly and kept at high level above $6.15 \mathrm{mg} / \mathrm{L}$ and its removal rate remained at $38.5 \%$ after 60 mins. By comparison, for initial chloride concentration $1000 \mathrm{mg} / \mathrm{L}$, the electrolysis rate remained almost unchanged with the time prolonged until the ammonia-N was removed completely. When the initial chloride concentration was $2000 \mathrm{mg} / \mathrm{L}$ and $3000 \mathrm{mg} / \mathrm{L}$, the ammonia-N concentration decreased much more quickly. The ammonia-N was removed completely in 50 mins and 40 mins. The electrolysis removal rate was obviously higher than that with low chloride ion concentration $1000 \mathrm{mg} / \mathrm{L}$ and $200 \mathrm{mg} / \mathrm{L}$.

Based on the above analysis, it can be concluded that, the higher the initial chloride ion concentration was, the higher the ammonia- $\mathrm{N}$ removal rate, and the shorter time for ammonia-N being removed completely. The removal rate has a good positive correlation with FRC in the simulated water. That reason was that 
the oxidation removal of ammonia- $\mathrm{N}$ mainly depending on the hypochlorite acid. By electrolysis, the chloride ion transformed to hypochlorite acid with strong oxidizability [27], that could oxidize ammonia-N quickly and effectively. So there was no rising trend in the first 30 mins for FRC. After the ammonia-N being completely removed, there is no other substances consumed FRC, so the chloride ion being used to produce FRC. During the process, the main products were nitrogen gas, a certain quantity of nitrite- $\mathrm{N}$ and nitrate-N [28], the oxidation process might refer to formula $(4,5,6)$, which would be proved in following experiments.

With the increase of chloride ion concentration, the nitrate-N concentration in outlet read from $12.74 \mathrm{mg} / \mathrm{L}$ to $8.55 \mathrm{mg} / \mathrm{L}$ and the removal rate rose from $36.3 \%$ to $57.3 \%$. The removal rate slowed down as time went on. The different removal rate of nitrate- $\mathrm{N}$ attribute to that the over-oxidation occurred [29] and the oxidation of intermediate product. It meant that part of ammonia- $\mathrm{N}$ and nitrite- $\mathrm{N}$ were oxidatived to nitrate- $\mathrm{N}$, similar to formula $(5,6)$, that was not what we needed, but the oxidative rate were very slow and did not dominate the whole reaction. This finding was consistent with the research by Sergi Garcia-Segura [28] and was to be certificated in the following experiment.

The experiment on nitrite- $\mathrm{N}$ accumulation was also depicted in Fig. 1. Nitrite-N accumulation was apparent and playing an important role as an intermediate product in the redox process. The conclusion did not confirm to Song who argued no nitrite-N accumulation occurred [6]. The nitrite-N concentration increased quickly within 10 mins, but over 10 mins, it kept almost constant. During the whole electrolysis process, the

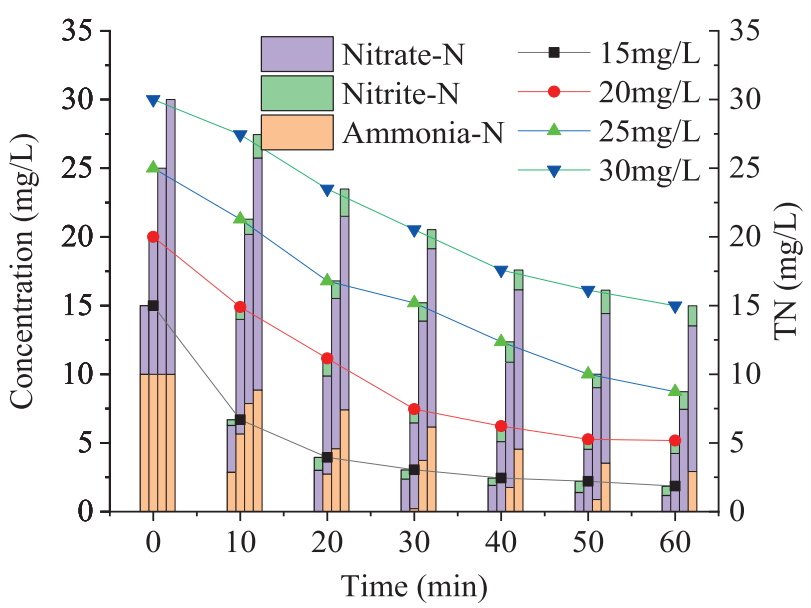

Fig. 3. Variation of the tested parameters with different initial nitrate- $\mathrm{N}$ concentrations. (On the column chart, the different color columns $\square$, $\square$ and also represent nitrate- $\mathrm{N}$, nitrite- $\mathrm{N}$ and ammonia-N, respectively; in each four-column group, the parameters were conducted under the respective 10,15 , $20,25 \mathrm{mg} / \mathrm{L}$ nitrate-N concentration from left to right and the ammonia-N concentration was $10 \mathrm{mg} / \mathrm{L}$; in the line+symbol diagram, The TN was also got under that condition.) reaction might follow the following reaction: the was absorbed on the surface of $\mathrm{Cu}$ cathode, obeying the reaction equations [30] below.

$$
\begin{gathered}
\mathrm{NO}_{3}^{-}+\mathrm{Cu} \rightarrow \mathrm{Cu}-\mathrm{NO}_{3}^{-} \\
\mathrm{Cu}-\mathrm{NO}_{3}^{-}+\mathrm{Cu} \rightarrow \mathrm{NO}_{2}^{-}+\mathrm{Cu}_{2} \mathrm{O}
\end{gathered}
$$

So nitrite-N was a key intermediate in the conversion from nitrate-N to nitrogen gas. With the increase of FRC concentration, the nitrite- $\mathrm{N}$ concentration increased, and the FRC could inhabit the process from nitrite-N to nitrogen gas to some extent. The degree of inhabitation varied with the different FRC concentration.

It also showed that when the initial chloride concentration was $3000 \mathrm{mg} / \mathrm{L}$, the nitrate- $\mathrm{N}$ and ammonia-N removal rate were the highest. Therefore, the next experiment was conducted with the chloride ion concentration $3000 \mathrm{mg} / \mathrm{L}$ and the concentration more approached the actual chloride ion concentration in real wastewater.

\section{Parameters under Different Nitrate- $N$ Concentrations}

The ammonia-N concentration in Fig. 3 decreased obviously with electrolysis time elapsing. It was removed completely with the time 20, 30, 50 mins when the initial nitrate- $\mathrm{N}$ concentration was 5, 10 and $15 \mathrm{mg} / \mathrm{L}$ correspondingly. But when the initial nitrate-N was $20 \mathrm{mg} / \mathrm{L}$, the ammonia- $\mathrm{N}$ was $2.92 \mathrm{mg} / \mathrm{L}$ with its removal rate $70.8 \%$.

Fig. 3 also depicted that the nitrate-N concentration showed a gentle decrease. Over 60 mins' electrolysis, the nitrate-N concentration was $1.81,4.27,7.45$ and $10.61 \mathrm{mg} / \mathrm{L}$ and the removal rate was $76.4,57.6,50.3$ and $47.0 \%$.

According to Fig. 3, the nitrite-N concentration was a little different under different initial nitrate-N concentrations. Those increased quickly in the first 20 mins and then began to fluctuate. For the initial nitrate- $\mathrm{N}$ being $20 \mathrm{mg} / \mathrm{L}$, within $10 \mathrm{mins}$, the nitrite- $\mathrm{N}$ concentration was the highest reaching about $1.5 \mathrm{mg} / \mathrm{L}$. For other initial nitrate-N concentrations, the accumulated nitrite- $\mathrm{N}$ concentrations were a little different, roughly lower than $1.5 \mathrm{mg} / \mathrm{L}$.

The higher the initial nitrate- $\mathrm{N}$ concentration, the lower the nitrite- $\mathrm{N}$ and ammonia- $\mathrm{N}$ removal rate. That meant a certain amount of nitrate- $\mathrm{N}$ transformed into nitrite- $\mathrm{N}$ and ammonia-N during the nitrate reducing process [31]. The generated ammonia-N and the accumulated nitrite- $\mathrm{N}$ concentration increased along with the rise of the initial nitrate-N concentration.

$\mathrm{TN}$ concentration in outlet was 1.9, 5.2, 8.7, $15.0 \mathrm{mg} / \mathrm{L}$, and its corresponding removal rate was $87.6 \%, 74.1 \%, 65.1 \%$ and $50.0 \%$. The difference of the TN removal rate mainly attributed to the different removal rate of ammonia-N. The $\mathrm{TN}$ maximum value was $15.0 \mathrm{mg} / \mathrm{L}$, which meant TN within 60 mins' electrolysis could meet the discharge standard $15 \mathrm{mg} / \mathrm{L}$. 


\section{Parameters under Different Ammonia- $N$ Concentrations}

The ammonia-N in Fig. 4 always kept a steady value 0 with the initial ammonia-N concentration $0 \mathrm{mg} / \mathrm{L}$ and there was no variation during the whole experiment. It indicated that the ammonia-N yielded rate was much lower than oxidation rate or there was no ammonia-N being produced by the reduction of nitrate-N. The ammonia-N was got rid of completely within $30 \mathrm{mins}$ when the initial ammonia-N concentration was $5 \mathrm{mg} / \mathrm{L}$. However, under the condition of $10 \mathrm{mg} / \mathrm{L}$, the removal rat was only $70.8 \%$ within 60 mins.

The nitrate-N reductions rate showed a slight difference, but was not dramatic. The ultimate TN concentration was $9.09,9.99$ and $10.61 \mathrm{mg} / \mathrm{L}$ respectively within 60 mins with corresponding removal rate being $54.6 \%, 50.1$ and $50.0 \%$. The different values could infer that different amount of ammonia- $\mathrm{N}$ was over-oxidized to nitrate-N.

When the initial ammonia-N concentration was null, nitrite-N still came out, which confirmed that it was the oxidation of ammonia- $\mathrm{N}$ that produced the nitrite-N. With the rise of the ammonia-N concentration, the nitrite-N concentration increased. There was a little higher for the nitrite-N with the initial ammonia-N concentration $10 \mathrm{mg} / \mathrm{L}$ than other both concentrations. The both were almost the same when the initial ammonia-N 0 and $5 \mathrm{mg} / \mathrm{L}$. The risen nitrite-N was produced by the oxidation of ammonia- $\mathrm{N}$, and its yield was related to initial ammonia- $\mathrm{N}$ concentration. The nitrite-N concentration would briefly remain within a certain range after 10 mins, their ultimate concentration was $0.8-0.9$ and $1.4 \mathrm{mg} / \mathrm{L}$ respectively after $60 \mathrm{mins}$.

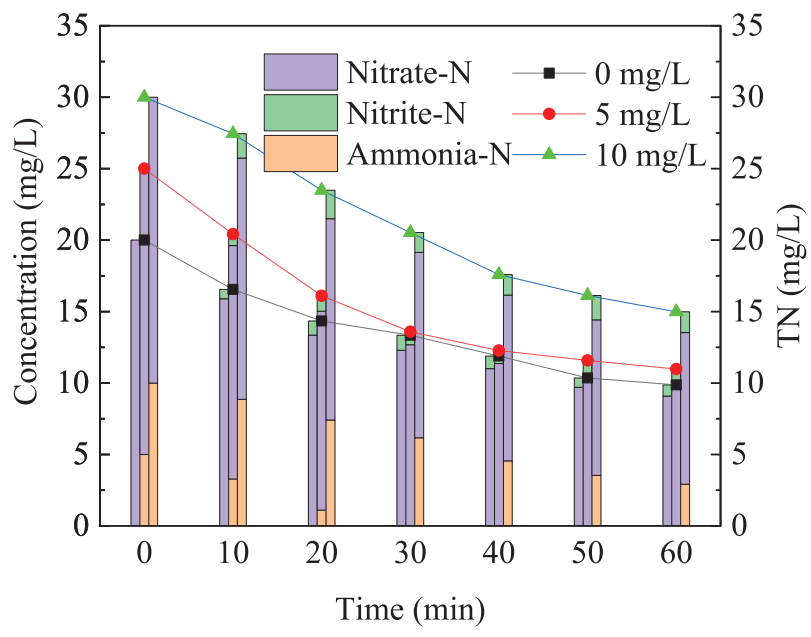

Fig. 4. Variation of the tested parameters with different initial ammonia-N concentrations. (On the column chart, the different color columns $\square, \square$ and $\square$ also represent nitrate- $\mathrm{N}$, nitrite-N and ammonia-N, respectively; in each three-column group, the parameters was conducted under the ammonia-N concentration were $5,10,15 \mathrm{mg} / \mathrm{L}$ from left to right and the nitrate-N concentration was $20 \mathrm{mg} / \mathrm{L}$; in the line+symbol diagram; the TN was also got under that condition.)
Furthermore, the transformation between ammonia-N and nitrate- $\mathrm{N}$ did occur and the nitrite was intermediate product.

For the TN removal, when the initial ammonia-N was 0 and $5 \mathrm{mg} / \mathrm{L}$, the removal rate shared a similar trend and both of them were lower than when the initial ammonia-N was $10 \mathrm{mg} / \mathrm{L}$. The differences turned up mainly at the beginning, which could owe to the existence of ammonia-N. The $\mathrm{TN}$ removal rate was mainly influenced by the removal of ammonia-N. The ultimate TN value was $9.9,11.0$ and $15.0 \mathrm{mg} / \mathrm{L}$ in 60 mins and their corresponding removal rate was 50.7, 56.1 and $50.0 \%$. All the final TN value met the discharge standard $15 \mathrm{mg} / \mathrm{L}$ within 60 mins' electrolysis.

\section{Parameters under Different COD Concentrations}

In Fig. 5, COD concentration decreased with the electrolysis time going on. But the COD removal rate was a little higher with the initial COD concentration increasing. The oxidation of COD by hypochlorous acid could account for the concentration decrease. COD removal rate of was positively correlated to the initial COD concentration. Over 60 mins, the COD value was 14.5, 25.4 and $29.8 \mathrm{mg} / \mathrm{L}$ and its corresponding removal rate was $27.5 \%, 36.4 \%$ and $50.3 \%$ respectively.

COD concentration had an obvious impact on the removal rate of ammonia- $\mathrm{N}$, and the impact occurred wihtin different time. Furthermore, the ammonia-N

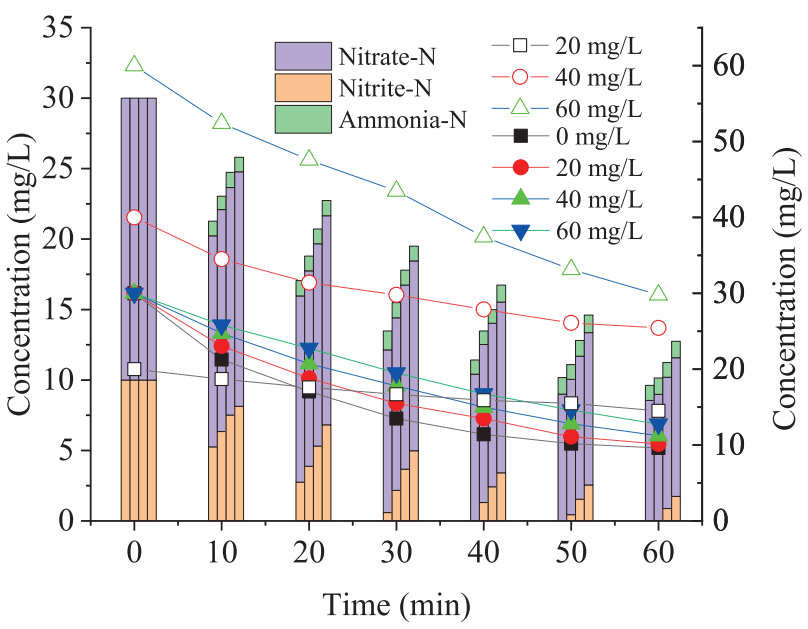

Fig. 5. The influence of COD concentration on TN, nitrate-N, nitrite-N and ammonia-N. (The different color columns $\square$, and $\square$ also represent nitrate-N, nitrite- $\mathrm{N}$ and ammonia-N, respectively; in each four-column group, the parameters were conducted under the ammonia-N and nitrate concentration were 10 and $20 \mathrm{mg} / \mathrm{L}$ respectively with COD concentration were 0 , $20,40,60 \mathrm{mg} / \mathrm{L}$ from left to right; in the line+symbol diagram, TN was got under four different COD concentrations depicted with four solid symbols; the variation of COD concentrations also showed with hollow symbols. TN and COD concentration was calculated on the right $Y$ axis.) 
removal rate decreased gradually with the rise of initial COD concentration. The ammonia-N removal rate was $100 \%$ when the initial COD concentrations were 0 and $20 \mathrm{mg} / \mathrm{L}$ within $60 \mathrm{mins}$. For the COD of $60 \mathrm{mg} / \mathrm{L}$, the value was $1.72 \mathrm{mg} / \mathrm{L}$ with the removal rate $82.6 \%$. The main reason of different ammonia- $\mathrm{N}$ removal rate attributed to the consumption of FRC by different COD concentration. More COD would consume more FRC, so the ammonia-N oxidation rate slowed down with the rising COD concentration.

The nitrate-N concentration decreased with the electrolysis time prolonged. There was a little difference of nitrate- $\mathrm{N}$ removal rate, the ultimate concentrations read $8.55,8.98,9.31$ and $9.84 \mathrm{mg} / \mathrm{L}$, all of which were below $10 \mathrm{mg} / \mathrm{L}$. All the nitrite-N concentration remained at around $1.1 \mathrm{mg} / \mathrm{L}$ after 10 mins. Furthermore, the nitrite-N concentration was almost not influenced by COD concentration. Therefore, the existing COD could have negative influence on the oxidation of ammonia-N. The oxidation of ammonia-N and COD also simultaneously happened, but no obvious influence on concentration change of nitrite-N. A little decelerating the reduction of nitrate- $\mathrm{N}$ compared without the existence of COD, all the nitrate-N values were below $10 \mathrm{mg} / \mathrm{L}$.

TN concentrations decreased and the removal rates increased with electrolysis time going by. COD had a negative impact on the removal of TN. The higher of the initial COD concentration, the lower of the TN removal rate. The differences of the TN removal rate were made by the removal of ammonia-N. The TN result values were 9.6, $10.1,11.2$ and $12.8 \mathrm{mg} / \mathrm{L}$ and their removal rates were $68.0 \%, 66.2 \%, 62.5 \%$ and $57.5 \%$. All the final TN values met the discharge standard $15 \mathrm{mg} / \mathrm{L}$.

\section{Conclusions}

The work was conducted by simulating the wastewater with high chloride ion concentration in secondary effluent of costal WWTP. The conclusions could be drawn as follows:

(1) Under different chloride ion concentration, when the initial ammonia-N was $20 \mathrm{mg} / \mathrm{L}$ and nitrate-N concentration was $10 \mathrm{mg} / \mathrm{L}$, the starting time for abrupt rise of the FRC had a positive correlation with the initial chloride ion concentration. The nitrate- $\mathrm{N}$, ammonia-N removal rate and the accumulation of nitrite- $\mathrm{N}$ increased with rising of FRC. Nitrate-N and ammonia-N could get the best removal rate under the condition of chloride ion concentration $3000 \mathrm{mg} / \mathrm{L}$.

(2) Under the constant ammonia-N concentration $10 \mathrm{mg} / \mathrm{L}$ and different nitrate- $\mathrm{N}$ concentration, the higher the initial nitrate- $\mathrm{N}$ was, the lower the ammonia-N removal rate was and the higher the nitrite-N accumulated. The TN got better removal rate, with the value between $87.6 \%$ and $50.0 \%$. Under the constant nitrate- $\mathrm{N}$ concentration $20 \mathrm{mg} / \mathrm{L}$ and different ammonia-N concentration, $\mathrm{TN}$ removal rate was greatly influenced by the existence of ammonia- $\mathrm{N}$, the TN removal rate being from $56.1 \%$ to $50.0 \%$. Under all the experiment conditions, the TN ultimate values all met the discharge standard of no higher than $15 \mathrm{mg} / \mathrm{L}$.

(3) Different COD concentrations could greatly influence the removal of ammonia-N but little for nitrate- $\mathrm{N}$ removal and nitrite-N accumulation. The transformation of nitrate- $\mathrm{N}$ and ammonia- $\mathrm{N}$ happened, the intermediate product nitrite- $\mathrm{N}$ could be produced by nitrate- $\mathrm{N}$ and ammonia- $\mathrm{N}$ and the value fluctuated between 0.5 and $1.5 \mathrm{mg} / \mathrm{L}$.

\section{Acknowledgements}

The authors gratefully acknowledge the funding from Doctoral Research Startup Fund of the North China University of Science and Technology, No. 28409899.

\section{Conflict of Interest}

The authors declare no conflict of interest.

\section{References}

1. XING W., LI D.S., LI J.L., HU Q.Y., DENG S.H. Nitrate removal and microbial analysis by combined microelectrolysis and autotrophic denitrification. Bioresource Technology, 211, 240, 2016.

2. DENG Y., CHEN N., FENG C. P., CHEN F.X., WANG H.H., KUANG P.J., FENG Z.Y., LIU T., GAO Y., HU W.W. Treatment of organic wastewater containing nitrogen and chlorine by combinatorial electrochemical system: Taking biologically treated landfill leachate treatment as an example. Chemical Engineering Journal, 364, 350, 2019.

3. Beijing Municipal Bureau of Environmental Protection, Beijing Municipal Bureau of Quality and technical supervision. Integrated Discharge Standard of Water Pollutant (DB11/07-2013). China, 4, 2006 [China].

4. HIRA D., AIKO N., YABUKI Y., YABUKI Y., FUJII T. Impact of aerobic acclimation on the nitrification performance and microbial community of landfill leachate sludge. Journal of Environmental Management, 209, 190, 2018.

5. FALÅS P., WICK A., CASTRONOVO S., HABERMACHER J., TERNES T. A., JOSS A. Tracing the limits of organic micropollutant removal in biological wastewater treatment. Water Research, 95, 243, 2016.

6. SONG Q.N., LI M, WANG L.L., MA X.J., LIU F., LIU $\mathrm{X}$. Mechanism and optimization of electrochemical system for simultaneous removal of nitrate and ammonia. Journal of Hazardous Materials, 363, 120, 2019.

7. ZHANG W., ZHOU Z., AN Y., DU S.L., RUAN D.N., ZHAO C.Y., REN N., TIAN X.C. Optimization for zeolite regeneration and nitrogen removal performance of a hypochlorite-chloride regenerant. Chemosphere, 178, 566, 2017.

8. TENG W., BAI N., LIU Y., LIU Y.P., FAN J.W., ZHANG W.X. Selective nitrate reduction to dinitrogen 
by electrocatalysis on nanoscale iron encapsulated in mesoporous carbon. Environ. Sci. Technol., 52, 230, 2018.

9. JOHN J., LEE D.K., SIM U. Photocatalytic and electrocatalytic approaches towards atmospheric nitrogen reduction to ammonia under ambient conditions. Nano Convergence, $\mathbf{6}, 15,2019$.

10. CUI X.Y., TANG C., ZHANG Q. A review of electrocatalytic reduction of dinitrogen to ammonia under ambient conditions. Adv. Energy Mater., 8 (22), 1800369:2, 2018.

11. GARCIA-SEGURA S., MOSTAFA E., BALTRUSCHAT $\mathrm{H}$. Electrogeneration of inorganic chloramines on borondoped diamond anodes during electrochemical oxidation of ammonium chloride, urea and synthetic urine matrix. Water Research, 160, 110, 2019.

12. DORTSIOU M., KATSOUNAROS I., POLATIDES C., KYRIACOU G. Influence of the electrode and the $\mathrm{pH}$ on the rate and the product distribution of the electrochemical removal of nitrate. Environmental Technology, 34 (3), 373, 2013.

13. KAMAI R., NAKANISHI S., HASHIMOTO K., KAMIYA K. Selective electrochemical reduction of nitrogen oxides by covalent triazine frameworks modified with single $\mathrm{Pt}$ atoms. Journal of electroanalytical chemistry, 800, 55, 2017.

14. SZPYRKOWICZ L., DANIELE S., RADAELLI M., SPECCHIA S. Removal of $\mathrm{NO}_{3}^{-}$from water by electrochemical reduction in different reactor configurations. Appl. Catal. B:Environmental, 66 (1-2), 41, 2006.

15. POLATIDES C., KYRIACOU G. Electrochemical reduction of nitrate ion on various cathodes-reaction kinetics on bronze cathode. Journal of Applied Electrochemistry, 35 (5), 421, 2005.

16. LIU Z.W., DONG S.S., ZOU D., DING J., YU A.Q., ZHANG J., SHAN C., GAO G.D., PAN B.C. Electrochemically mediated nitrate reduction on nanoconfined zerovalent iron: Properties and mechanism. Water Research, 173, 5, 2020.

17. ZHANG G.Y., SHI Y.H., ZHANG H.M., YANG F.L., CAI L. Operation adjustments of an electrochemically coupled system for total nitrogen removal and the associated mechanism. Chemosphere, 246, 4, 2020.

18. ZHANG Y., LI J.H., BAI J., SHEN Z.X., LI L.S., XIA L.G., CHEN S., ZHOU B.X. Exhaustive conversion of inorganic nitrogen to nitrogen gas based on a photoelectrochlorine cycle reaction and a highly selective nitrogen gas generation cathode. Environ. Sci. Technol., 52 (3), 1413, 2018.

19. LUU T.L., KIM J., YOON J. Physicochemical properties of $\mathrm{RuO}_{2}$ and $\mathrm{IrO}_{2}$ electrodes affecting chlorine evolutions. Journal of Industrial and Engineering Chemistry, 21, 401, 2015.

20. ZHI D., ZHANG J., WANG J.B., LUO L., ZHOU Y.Z., ZHOU Y.Y. Electrochemical treatments of coking wastewater and coal gasification wastewater with $\mathrm{Ti} / \mathrm{Ti}_{4} \mathrm{O}_{7}$ and $\mathrm{Ti} / \mathrm{RuO}_{2}-\mathrm{IrO}_{2}$ anodes. Journal of Environmental Management, 265, 3, 2020.

21. YAO J.C., ZHOU M.M., WEN D.N., XUE Q.W., WANG J.D. Electrochemical conversion of ammonia to nitrogen in non-chlorinated aqueous solution by controlling $\mathrm{pH}$ value. Journal of Electroanalytical Chemistry, 776, 54, 2016.

22. HASHEMZADEH M., LIU W.Y. Analysis of iron and copper speciation and activities in chloride leaching solutions of high ionic strength. Hydrometallurgy, 192, 5, 2020.

23. GUHA A., NARAYANARU S., KALEY N.M., RAO D.K., MONDAL J., NARAYANAN T.N. Mechanistic insight into high yield electrochemical nitrogen reduction to ammonia using lithium ions. Materials Today Communications, 21, 2, 2019.

24. SU L.H., LI K, ZHANG H.B., FAN M.H., YING D.W., SUN T.H., WANG Y.L., JIA J.P. Electrochemical nitrate reduction by using a novel $\mathrm{Co}_{3} \mathrm{O}_{4} / \mathrm{Ti}$ cathode. Water Research, 120, 6, 2017.

25. LI L., YUN Y.F., ZHANG Y.Z., HUANG Y.X., XU Z.H. Electrolytic reduction of nitrate on copper and its binary composite electrodes. Journal of Alloys and Compounds, 766, 158, 2018

26. KUANG P., NATSUI K., EINAGA Y. Comparison of performance between boron-doped diamond and copper electrodes for selective nitrogen gas formation by the electrochemical reduction of nitrate. Chemosphere, 210, 526, 2018.

27. ZHANG C.Y., HE D., MA J.X., WAITE D. Active chlorine mediated ammonia oxidation revisited: Reaction mechanism, kinetic modelling and implications. Water Research, 145, 223, 2018.

28. GARCIA-SEGURA S., LANZARINI-LOPES M., HRISTOVSKI H., WESTERHOFF P. Electrocatalytic reduction of nitrate: Fundamentals to full-scale water treatment applications. Applied Catalysis B: Environmental, 236, 550, 2018.

29. DENG Y., CHEN N., FENG C.P., CHEN F.X., LIU H.W., CHEN Z.Q. Enhancing electrochemical treatment of nitrogen-containing organic wastewater by iron filings: Performance, inhibition of organochlorine byproducts accumulation and cost-effectiveness. Chemical Engineering Journal, 384, $3,2020$.

30. ZHANG Y., LI J.H., BAI J., LI X.Y., SHEN Z.X., XIA L.G., CHEN S., XU Q.J., ZHOU B.X. Total organic carbon and total nitrogen removal and simultaneous electricity generation for nitrogen-containing wastewater based on the catalytic reactions of hydroxyl and chlorine radicals. Applied Catalysis B: Environmental, 238, 174, 2018.

31. BOSKO M. L., RODRIGUES M. A. S., FERREIRA J. Z., MIRÓ E.E., BERNARDES A.M. Nitrate reduction of brines from water desalination plants by membrane electrolysis. Journal of Membrane Science, 451, 281, 2014. 